May 2014

\title{
First Class: Pioneering Students at San José State University's School of Library and Information Science, 1928-1940
}

Debra L. Hansen

San Jose State University, Debra.Hansen@sjsu.edu

Follow this and additional works at: https://scholarworks.sjsu.edu/ischoolsrj

Part of the Library and Information Science Commons, United States History Commons, and the Women's History Commons

Acknowledgements

The author thanks Lisa Blank for providing the initial idea for this article. Inspiration was drawn from Dr. Blank's 2013 master's thesis that studied the lives and work of students in Redondo Beach Public Library's training program.

\section{Recommended Citation}

Hansen, D. L. (2014). First Class: Pioneering Students at San José State University's School of Library and Information Science, 1928-1940. School of Information Student Research Journal, 4(1). https://doi.org/ 10.31979/2575-2499.040102 Retrieved from https://scholarworks.sjsu.edu/ischoolsrj/vol4/iss1/2

This article is brought to you by the open access Journals at SJSU ScholarWorks. It has been accepted for inclusion in School of Information Student Research Journal by an authorized administrator of SJSU ScholarWorks. Formore information, please contact scholarworks@sjsu.edu. 


\title{
First Class: Pioneering Students at San José State University's School of Library and Information Science, 1928-1940
}

\author{
Abstract \\ This article examines the backgrounds, education, and careers of the first group of students in San José \\ State University's School of Library and Information Science. It finds that the 1928-1929 cohort were \\ typical of the students attending teacher's colleges in the early 1900 s and represented the first generation \\ of women pursuing higher education and professional careers following the passage of the $19^{\text {th }}$ \\ amendment in 1920. The study also explores the challenges working women faced during the 1930s, \\ particularly the Great Depression's impact California librarians.

\section{Keywords} \\ Women librarians; library history; California libraries; library education; San José State Teacher's College

\section{Acknowledgements} \\ The author thanks Lisa Blank for providing the initial idea for this article. Inspiration was drawn from Dr. \\ Blank's 2013 master's thesis that studied the lives and work of students in Redondo Beach Public \\ Library's training program.

\section{About Author} \\ Dr. Debra Hansen is a professor at San Jose State University's School of Library and Information Science. \\ She currently teaches courses in the history of books and libraries, historical research methods, and \\ information and society. She earned an MLIS from UCLA and a doctorate from the University of California, \\ Irvine, where she specialized in 19th century American social and women's history.
}


The new education needs the service of the library teacher who can teach children to use printed material efficiently. In the past we have been too afraid that some teacher untrained in the essentials of librarianship would enter our field of work; we should have been afraid that we who know about librarianship should fail as teachers. School librarianship is a big responsibility. Let us all be "library teachers!" (Beymer, 1933, p. 9)

As school librarianship took shape as a new profession in the early 1930s, a point of controversy arose over the appropriate training for the field. Should the person in charge of the school library be a teacher with librarianship as a teaching specialty? Or was the school library, like any other library, to be administered by a degreed librarian? Mildred Beymer (1933), as evidenced by her California School Library Association (CSLA) Bulletin editorial quoted above, believed that a school librarian was first and foremost a teacher and merited being treated as such in the school where she worked. Why should the school librarian "carry her professional cognomen into the school," Beymer reasoned, when other teaching specialists in music, science, home economics, etc., did not (p. 9)?

Beymer's position on the teacher-librarian debate is not surprising. As one of the first graduates of San José State Teachers College's new library science program, her professional identity was shaped by and within the teaching field. Not only did she earn a BA in education (with a librarianship major) in 1930, during her schooling she had achieved membership in Kappa Delta Pi, an honor society for education majors. When she penned her editorial several years later, she was engaged as a teacher librarian at San Francisco's Roosevelt Junior High School. 
This article examines the background and experience of the first group of students in San José State University's School of Library and Information Science (SLIS). Set within the broader context of state teachers colleges and the role these institutions played in developing and promoting women's professional work in the 1920s, this article analyzes how SLIS's pioneering students both represented and deviated from the typical teachers college student. It also considers the Great Depression's impact on the advancement of women in the professions, using the SLIS cohort to illustrate the challenges working women faced and how they confronted and, quite often, surmounted them.

\section{San José State Teachers College}

Established in 1857, San José State Teachers College had been educating elementary and high school teachers for over seventy years. Originally a "normal school" that exclusively awarded the teaching credential, in 1921 the college began offering a bachelor of arts degree and over the next decade continued to add new programs. As President Thomas MacQuarrie explained in his 1929 state of the school speech:

We have developed out of the field of a limited teacher training institution, and we are rapidly taking on the character of the modern, municipal college .... Our organization, as it stands, is unique in college history, and many eyes are watching with interest the development taking place here. (La Torre, 1929 p. [15])

In the 1928-1929 academic year alone, San José State added four new degrees: nurse's training, commerce (i.e. secretarial training and accountancy), speech and stage craft, and librarianship (Greathead, 1928, p. 51). The predominance of feminized professions in these new programs clearly reflected the college's current demographics, since more than two-thirds of San 
José State's 1,500 students were women (San José State Teachers College Bulletin, 1928/1929), p. 29).

According to Christine Ogren (2000), state teachers colleges—and their precursors, state normal schools - typically had a majority of women students preparing for careers in teaching or other education-based fields. In her study of seven state normal schools (including San José State), Ogren found that these teaching institutions "created an environment in which women could blossom" while affording them educational and professional opportunities often denied them by more exclusive and expensive universities (p. 213). Whether male or female, observed Ogren, the typical teachers college student was "mature in years, from a small provincial town or village, experienced in the workforce as a teacher or farmer, not well-off financially, and the first in the family to be educated beyond the common school" (p. 212). Moreover, as teachers colleges expanded in the 1920s, some women who otherwise might have become teachers pursued nontraditional fields such as law and politics (p. 225). Often postponing marriage to work in their chosen profession, these single women enjoyed opportunity and independence unknown to previous generations.

San José State's development of new degrees reflected not only women's increasing independence and expanding employment options in the 1920s, but also the professionalization of traditionally female occupations, such as teaching and librarianship (Scharf, 1980; Weiler, 2011). In California, for example, the state legislature established the Department of Education in 1921, and during the ensuing decade that agency improved the state's educational system and upgraded standards for teachers. As part of this modernization effort, the department gradually increased the requirements for teacher certification so that by 1930 California teachers were expected to have a four-year baccalaureate degree in education. The Department of Education 
also created a series of specialized teaching credentials in subject areas requiring advanced knowledge and training (Commission on Teacher Credentialing, 2011). Among these new degrees was the special credential in librarianship.

\section{San José State's Department of Librarianship}

Administrators and faculty at San José State's Teachers College closely monitored these state-mandated changes and acted quickly to develop courses satisfying the new degree requirements. The task of designing courses for the new school library credential fell to the college librarians. Constituting themselves as the "Department of Librarianship," head librarian Joyce Backus directed the new program while the librarians served as its faculty. With professional degrees from some of the nation's premier library science programs, including Simmons College (Joyce Backus), Columbia University (Helen Bullock), University of California, Berkeley (Joy Belle Jackson and Ruby Kerr), and Pittsburgh's Carnegie Institute (Emelyn Beattie), San José State's librarians were well prepared to create the new curriculum (Hansen, 2010). According to Backus, the department also enjoyed "splendid cooperation" from other San José State faculty who stepped forward during the first year to teach courses. Among others, Arthur Caryl of the Commerce Department offered a course on budgets and accounts, while the Art Department's Susan Byrne and Estelle Hoisholt developed courses on bookbinding and lettering (“Department of Librarianship," n.d., SJSU Archives, Box 139, Folder “1928/29).

Recognizing California's growing need for professional librarians, Backus and her library colleagues sought to create a curriculum that would simultaneously meet the requirements of the new teacher librarian credential and prepare students for work in other types of libraries. "While our objectives are chiefly training for school library work," explained Backus in her annual 
report, "we'd like to fill the need for undergraduate training ... which qualifies [students] for library work in the smaller libraries" ("Department of Librarianship," n.d., SJSU Archives, Box 139, Folder “1928/29”).

San José State's librarians were mindful that their future students would likely be mature women with varying educational and professional backgrounds and needs. Accordingly, the librarians devised three educational options: 1) bachelor of arts degree that qualified an individual for both teaching and librarianship credentials; 2) bachelor of arts degree with a librarianship major that qualified an individual solely for the special credential in librarianship; and 3) one-year post-graduate program in librarianship for students who already had a bachelor's degree or teaching credential and were seeking only the librarianship credential. The department also supported a two-year junior college degree for students desiring training for "minor" positions in local libraries (San José State Teachers College Bulletin, 1928/1929, p. 108-111).

\section{SLIS's First Students}

Twelve full-time and five special students enrolled in San José State’s library science program during its initial year. To be admitted, the full-time students had to have completed two years of college, possess reading knowledge of two languages, and be able to "typewrite accurately" (Board of Education for Librarianship Report, 20 November 1928, American Library Association Archives). The special students did not meet the college's entrance requirements, but because they had prior library training or work experience they were allowed to take courses to advance their careers (San José State Teachers College Bulletin, 1928/1929, p. 108-109). According to Backus, this first cohort was "enthusiastic and interested in their work" and helped get the program off to a "rather promising beginning" ("Department of Librarianship," n.d., SJSU Archives, Box 139, Folder “1928/29”). 
The names of 11 of these pioneering students have been identified: Edna B. Williams, Bertha "Benicia" de Niedman, Hollis V. Knopf, Grace Laughton, Mildred Beymer, Adelyn Skonovd, Bernice Sheld, Marian Bambauer, Elizabeth Souther, Doris M. Garcelon, and Dorothy E. Wood (Anita Hostedter to Joyce Backus, 5 February 1929, ALA Archives). Interestingly, their personal and professional lives were quite similar to the teachers college students depicted in Ogren's study (2000) discussed above. As expected, all students were women. In fact, it would be over two decades before San José State's Department of Librarianship would have its first male student. Also consistent with Ogren's model, the first group of students were fairly mature, with an average age of 28. This figure is somewhat misleading, though, as the students' actual ages varied significantly. Hollis Knopf and Dorothy Wood were just 19, while Adelyn Skonovd, Marian Bambauer, Mildred Beymer, Benicia de Niedman, and Bernice Sheld were in their twenties. Meanwhile Grace Laughton was in her thirties, while Doris Garcelon, Elizabeth Souther, and Edna Williams were in their forties. ${ }^{1}$

Most of the younger women were already working on degrees at San José State when they entered the new librarianship program. Knopf, for instance, had earned a junior college certificate in 1928 and finished her BA in 1930 (La Torre, 1928, p. 62; La Torre, 1930, p. 41). Skonovd and Baumbauer completed their BAs in 1929, while de Niedman, Beymer, and Wood graduated in 1930 (La Torre, 1929, p. 43, 52; La Torre, 1930, p. 45, 197). Several students were enrolled in other schools prior to entering San José State. Sheld had been a student at Modesto Junior College, while Beymer attended Riverside Public Library's training school and was working in the Riverside library before moving north. Although there is no record of Sheld graduating from San José State, Beymer (as noted above) was awarded her BA in 1930.

\footnotetext{
${ }^{1}$ Unless otherwise noted, this section's data comes from the genealogy records available through the Ancestry.com database. Most important were U.S. census reports, birth and death records, city directories, and voter registration records.
} 
The program's more mature women were typically re-entry students who during the 1920s had been working and/or raising families. Thirty-four-year-old Grace Limerick Laughton, for example, had been a San José State student in the early 1920s, graduating with her BA in 1922. Thereafter she married and taught for several years-first in San José and later in Modesto—-before returning to study library science. Edna Williams Murphy also previously attended San José State, graduating in 1915. Married with one child, it seems likely that she lived with or near her parents in Mountain View when she took library science courses in the late 1920s.

At 42, Elizabeth Souther was the library science program's oldest student. She had been employed in the San José area at least since 1920, including two years of secretarial work at San José State (La Torre, 1923, p. 19; La Torre, 1924, p. 14). After living in Oakland for a couple of years while attending school (most likely UC Berkeley or Mills College), she was back in San José in 1926 and working for the county superintendent of schools. In 1928, when she started taking library science courses, she was a San José Public Library employee.

Also similar to the model established by Ogren, the majority of SLIS's first students came from middle- and working-class backgrounds, though here again there were several exceptions. ${ }^{2}$ All of the women were white and American-born. Six were California natives while others were born in Minnesota, Nebraska, Illinois, and Missouri. Their parents had more diverse backgrounds. Only two hailed from California originally, while others came from Illinois, Missouri, Minnesota, Iowa, Pennsylvania, and Ohio. Moreover, some were foreignborn: de Niedman's father was Russian, Sheld's parents Swedish, Garcelon's father Canadian, while Skonovod's parents were Norwegian and Swedish. Interestingly, except for Souther, all of

\footnotetext{
${ }^{2}$ Because of her common name and no identifying attributes in the San José State yearbooks and archives, verifiable family information for Dorothy Wood could not be located.
} 
the students' parents migrated to California before or during their daughters' schooling in San José. In terms of class background, four of the students' fathers were farmers, one was a dairyman, and one ran a livery stable. Three other fathers, however, were professional men: Laughton's father a clergyman; de Niedman's father a U.S. Army surgeon; and Souther's father a banker. Among the students' mothers, only two had identified occupations: Skonovd's mother was a seamstress, while de Niedman's mother was a teacher.

Also true to Ogren's model, the women seeking their library degrees were in the first generation of their families to attend college. Based on data from the 1940 census, which asked respondents to indicate education level, those parents still living typically had either an eighthgrade education or several years of high school. ${ }^{3}$ Here again there were a couple of interesting exceptions. De Niedman's father earned both medical and dentistry degrees from Howard University and her mother was a Kansas State Normal School graduate. Baumbauer's mother also had two years of college, though her father only went through the eighth grade.

One of the important byproducts of a college education, argues Ogren, is that "women were taken seriously as scholars" and introduced to leading writers and intellectuals of their time. They also participated in extracurricular activities, such as sports and debating societies, all of which “conveyed subtle lessons about women's potential” (p. 213). As their library science coursework was part of a four-year college degree, SLIS's first cohort similarly benefitted from this stimulating environment. They took a full array of professional courses (namely, cataloging, classification, reference, book selection, library administration, and school libraries), and, at the same time, were encouraged to enroll in academic classes to expand their general knowledge. Emphasizing the humanities and social sciences, the recommended courses for library science majors covered modern languages, art, child psychology, sociology, world literatures,

\footnotetext{
${ }^{3}$ This data is limited as only 11 parents were still living in 1940.
} 
philosophy, and modern history (San José State Teachers College Bulletin, 1928/1929, p. 112114).

Several of the students were also involved in campus activities. Knopf was a member of Der Deutsche Verein [German Club] and served on the YWCA Committee (La Torre, 1927, 1928). De Niedman was an editor of The Quill, a monthly literary magazine published by the English Club from 1925-1931 (La Torre, 1928, p. 165). The organization that attracted most library science students was Kappa Delta Pi, a national honor society for education majors established in 1911at the University of Illinois (Kappa Delta Pi, 2010). Wood, Bambauer, Beymer, and de Niedman were all members of this organization, with de Niedman serving as the organization's reporter in 1927 and Wood as the assistant treasurer in 1930 (La Torre, 1927, 1930). ${ }^{4}$

All of the first cohort members, save one, finished their studies by 1930, with Laughton completing her BA in 1932 (La Torre, 1932, p. 48). ${ }^{5}$ Interestingly, in light of the 1929 stock market crash and the deepening economic depression, most were able to secure employment within a year or two of graduation. Bambauer, de Niedman, Beymer, and Laughton found positions in public schools. Frustratingly, the primary records for employment history—city directories, voter registration, and U.S. census reports—indicate only "teacher" as these women's occupation, so it cannot be positively determined if they were working as librarians. Yet, given the prevailing sentiment that school librarians were teachers specializing in librarianship, it's very likely that they were in charge of their respective school library. Mildred Beymer provides a good case in point. She is listed in the 1931 San Francisco city directory as a

\footnotetext{
${ }^{4}$ Interestingly, Kappa Delta Pi, unlike its rival honor society Phi Delta Kappa, allowed women and ethnic minorities to become members from its start (Kappa Delta Pi, 2010, p. 1-2).

${ }^{5}$ Not all of the students earned their BAs but did take enough coursework to qualify for city and county library positions.
} 
"teacher." Yet, according to the School Library Association of California Bulletin (1936), she was the librarian at Roosevelt Junior High School (p. 23).

Other SLIS pioneers found jobs in academic and public libraries. Two were employed by college libraries: Knopf at Marin Junior College and Garcelon at Humboldt State College. Other graduates began their careers in public and county libraries. Souther continued working in the San José Public Library, Wood found employment in the Plumas County Library, while Sheld eventually landed a position in the Ceres branch of the Stanislaus County Library System.

Employment records for two of the students, Adelyn Sknovod and Edna Murphy, could not be found. Baumbauer and Wood also disappeared from the public record after 1931. This does not necessarily mean that they never worked as librarians or permanently left the profession early in their careers. Rather, it is more a reflection of record-keeping practices at that time and the prevailing attitudes that shaped them. The U.S. census recorded many personal details about family members, but omitted a married woman's maiden name. As a result, once a woman married her former self virtually disappeared. Similarly, city directories routinely included a woman's name, address, and occupation—until she married. Thereafter, a wife's name was listed in parentheses after her husband's, with no occupation indicated or expected. These "parenthetical" women also became effectively anonymous within the historical record.

The disappearance of married women from standard employment records also reveals the challenges women faced in the workplace, particularly in the 1930 s. ${ }^{6}$ During the Great Depression, because women were stigmatized as taking jobs away from family men, there was pressure on them to stop working after marriage (Ware, 1982, p. 27-28). As Lois Scharf (1980) found in her study of working women in the 1930s, even in feminized professions like

\footnotetext{
${ }^{6}$ Ogren's 2000 study, which derives from data collected as part of her PhD dissertation, ends at 1920. As a result, her analysis did not address the impact of the Great Depression on women college graduates.
} 
librarianship, women often were replaced by men or forced to accept reduced wages. As an example, Scharf cites a 1938 survey of 57 libraries that inquired about institutional policies regarding married women. "Twelve of the libraries required resignation upon marriage, nine reported that wives were retained with temporary status, [and] ten stated they would not place a married woman in a position that entailed responsibility" (p. 103). As a result of this discrimination, by 1940 only $20 \%$ of employed librarians were married, as compared to $35.5 \%$ of working women overall (Scharf, p. 103).

Despite this social pressure, both unmarried and married women continued to work throughout the Depression. Unmarried women not only provided for themselves, they often lived with and supported their aging parents. Many married women also had to work to offset the lost wages of their unemployed or underemployed husbands. In fact, historians have found that despite prevailing attitudes regarding women and work, between 1930 and 1940 the overall number of women in the workforce increased by 2 million and the number of working married women doubled (Ware, 2009).

It was within this context, then, that the first graduates of San José State's library science program carved out careers, and their varied experiences exemplify the opportunities, limitations, and expectations of the time. At least five of the students are known to have married: Edna Murphy Williams, Mildred Beymer Graham, Hollis Knopf Erickson, Grace Limerick Laughton, and Adelyn Skonovd Lorraine. Murphy, Beymer and Skonovd had children, while Knopf and Laughton did not, though the 1930 U.S. Census indicates that Laughton's household included her mother and twin nieces.

These married women's careers appear to have been heavily influenced by their personal situation and their husband's status. Prior to their marriages, Beymer and Knopf not merely 
found employment but quickly became involved in the profession. In addition to her job as a teacher-librarian at Roosevelt Junior High School, Beymer edited both the School Library Association of California (CSLA) Bulletin (1932-1933) and the CSLA Handbook. She also served on CSLA's Northern Section Elementary School Committee in 1930. While working at Marin Junior College, Knopf was also very involved in the professional library community. In the seven years following her graduation, she was associate editor of the CSLA Bulletin (19321933), CSLA Northern Section Secretary (1933-1935), CSLA Northern Section President (19351936), and CSLA Director (1936-1937). She also penned a regular column, "Wrinkles and Gadgets," in the CSLA Bulletin devoted to professional news and innovations.

Despite this dynamic start to their careers, marriage eventually curtailed both Beymer's and Knopf's professional engagement. Beymer married Everett Marvin Graham in 1934, and two years later the CSLA Bulletin (1936) reported, "Mrs. Mildred Beymer Graham, editor of the Handbook and for several years librarian of Roosevelt Junior High School in San Francisco, has resigned to take up the duties of housewife" (p. 23). Knopf, who married Herbert Erickson in 1935, continued working a bit longer, during which time she was instrumental in designing Marin Junior College's new library (Erickson, 1940). But in November 1941, the CSLA Bulletin ran a similar notice: "Hollis Erickson has decided that she wants more time to enjoy her home and her husband's company, and so she has taken a year's leave from Marin Junior College Library and is living near Campbell" (p. 18). The absence of subsequent employment data relating to these two women suggests that neither Beymer nor Knopf returned to the field.

Beymer and Knopf were fortunate to have employed husbands who were able to support their families during the depths of the Depression. ${ }^{7}$ Other married SLIS graduates had more

\footnotetext{
${ }^{7}$ Beymer's husband was a chemist, while Knopf's owned a successful van and storage business. Both husbands had two years of college education as well.
} 
unstable situations which, ironically, helped keep them in the profession. Grace Laughton provides a good example. She worked as a teacher in the Firebaugh (Fresno County) public schools before entering San José State's library science program, and after graduation she returned her former employer. She continued to work for most of the 1930s as a teacherlibrarian in Firebaugh; however, her husband Calvin—a barber by trade—lived and worked in another part of the state. Apparently, in 1934 Grace reunited with Calvin in San José; he was listed in the city directory as a barber; she was included parenthetically. But within two years Grace returned alone to her former teaching post in Firebaugh, once again self-supporting.

Single women also had their careers shaped by family circumstances and responsibilities. First-generation Swedish-American Bernice Sheld finished only three years of college before returning to Modesto in 1930 to live with her parents. She never married and would live with or near her parents for the rest of their lives. Initially, Sheld worked as a bookkeeper for a prominent Modesto architect. Then, in January 1934, she became librarian at the Ceres Public Library. She worked there until December 1944, when she resigned to return to her former bookkeeping job with the Modesto architect (Modesto Bee, 27 December 1944). Sheld's decision to leave the library in late 1944 was likely influenced by her father's failing health, as he died in March 1945. Although already back living with her parents (she had lived alone in Ceres for several years), perhaps Sheld needed a higher wage or more flexibility. She lived with her widowed mother and worked as a bookkeeper until 1953, when she became a social worker for the county welfare office. She remained in this position until her early 1960s retirement. An only child, ${ }^{8}$ Benicia de Niedman also lived with, and perhaps helped support, her father and stepmother while employed as a teacher-librarian in San José. After her father's death

\footnotetext{
${ }^{8}$ De Niedman's half-brothers from her father's first marriage died in 1906 and 1907, the result of diseases contracted in the wake of the 1906 San Francisco earthquake. The photographs taken by Theodore de Niedman of
} 
in 1938, de Niedman spent several years on her own in Pacific Grove, working in the public schools. By 1942, however, she was back living with her stepmother in San José and employed as a teacher-librarian. She would live and work in San José until her death in 1948.

Finally, Elizabeth Souther and Doris Garcelon, neither of whom married, both had long professional careers in public libraries. Souther, who was 44 in 1930, continued to work at San José Public Library during her time as a library science student. Then in 1933 she became librarian at Palo Alto Public Library, where she stayed for at least another decade. Garcelon obtained her first professional position in 1931 near her family's Eureka home at Humboldt State College. However, within a few years she moved back to the Bay Area with her widowed mother to take a job at the Redwood City Public Library. Sometime in 1941 Garcelon's mother returned to Arcata where she died in December 1942. Now independent, Doris moved further south to become librarian at the San Luis Obispo Public Library, where she stayed until retiring in the late 1950s.

\section{Conclusion}

September 1928 seemed an auspicious time for San José State College to start its new degree in school librarianship. The college had enjoyed a decade of steady growth, expanding its academic programs and modernizing its library and other campus facilities (Hansen, 2010). The college now offered a bachelor of arts degree in a variety of fields, giving its students-the majority of whom were women—a promising outlook for gainful employment. Few would have foreseen the economic disaster that began several months later as the nation faced a severe economic downturn. Especially hard hit were service professions dependent on government 
funding like teaching and librarianship. Societal factors, too, played an important role in discouraging middle-class women from entering the workplace during this trying decade.

The seventeen women who comprised San José State's first class were true pioneers. Primarily from working-class backgrounds, they were the first in their families to attend college and, upon graduation, find professional employment. In the process, they helped establish the college's new teacher-librarian program and then used their education to professionalize the libraries in which they worked. Given the challenging time, most of these women had to adjust their career plans in response to family needs and societal expectations. Yet a majority were able to enjoy substantial, if rather short-lived, professional careers.

To survive during the Great Depression, San José State's library science program had to adopt a similar strategy. Initially the founding faculty had ambitious plans, hoping to provide education for not only teacher-librarians but for other types of library work as well. However, the realities of library employment, combined with the pressures of accreditation, convinced head librarian Backus and her colleagues to modify their original goals and to focus exclusively on educating school librarians (Parker, 1974, pp. 23-24). San José State would continue to teach its library science courses within the School of Education for another two decades, waiting until the early 1950s to return to its original plan of offering a comprehensive library and information science degree. 


\section{References}

Beymer, M. L. (1933). What's in a name: Editorial comment. California School Library Association Bulletin, 6(1), 9.

Blank, L. (2013). Made Marion: Myth and reality in the Redondo Beach Public Library, 18951924. (Unpublished master's thesis). San José State University. San José, CA.

Commission on Teacher Credentialing. (2011). A history of policies and forces shaping California teacher credentialing. Sacramento: California Commission on Teacher Credentialing. Retrieved from http://www.ctc.ca.gov/commission/files/CTC-history.pdf

Erickson, H. V. (1940, November). New library at Marin Junior College. California School Library Association of California Bulletin, 12,10.

La Torre. (1928). San José: Associated Students of San José State College.

La Torre. (1929). San José: Associated Students of San José State College.

La Torre. (1930). San José: Associated Students of San José State College.

Hansen, D. G. (2010). A pioneering and independent spirit: The History of San José State University's School of Library and Information Science. Victoria, B.C.: Trafford.

Kappa Delta Pi. (2010). Kappa Delta Pi: The first hundred years. Retrieved from http://www.kdp.org/aboutkdp/pdf/KDP_Brief_History.pdf

Modesto Bee, 27 December 1944.

Ogren, C. A. (2000). A large measure of self-control and personal power: Women students at state normal schools during the late-nineteenth and early-twentieth centuries. Women's Studies Quarterly, 28(3/4), 211-232.

Parker, M. R. (1974). A history of the Department of Librarianship at San Jose State University, 1928-1969 (Unpublished master’s thesis). San José State University, San José, CA. 
San José State Teachers College Bulletin. (1928/1929). San José: San José State University.

Scharf, L. (1980). To work and to wed: Female employment, feminism, and the Great Depression. Westport, CT: Greenwood Press.

Mrs. Mildred Beymer. (1936). California School Library Association Bulletin, 8(1), 23.

Ware, S. (1982). Holding their own: American women in the 1930s. Boston: Twayne.

Ware, S. (2009, Spring). Women and the Great Depression. History Now, 9. Retrieved from http://www.gilderlehrman.org/history-now/2009-03/great-depression

Weiler, K. (2011). Democracy and schooling in California: The legacy of Helen Heffernan and Corinne Seeds. New York: Palgrave. 